\title{
Produktivitas Rumput Raja (Pennisetum purpupoides) pada Pemotongan Pertama Menggunakan Beberapa Sistem Pertanian
}

\author{
Productivity of King Grass (Pennisetum purpupoides) at the First Harvest \\ Using Three Farming Systems
}

\author{
Suyitman \\ Fakultas Peternakan Universitas Andalas \\ Kampus Unand Limau Manis, Padang 25163 \\ e-mail: suyitman_psl@yahoo.co.id \\ (Diterima: 28 Desember 2013; Disetujui: 21 Maret 2014)
}

\begin{abstract}
ABSTRAK
Tujuan penelitian menentukan pengaruh sistem pertanian; anorganik, LEISA (Low External Input and Sustainable Agriculture) dan organik pada produktivitas Rumput Raja, ketika panen pertama. Penelitian menggunakan pupuk N, P, K, pupuk kandang dan vesikular arbuskular mikoriza (VAM). Penelitian memakai analisis varians dengan randomized block design (RBD) yang terdiri dari 5 perlakuan dan 4 ulangan. Perlakuannya adalah A $(200 \mathrm{~kg} \mathrm{~N}: 150 \mathrm{~kg} \mathrm{P}: 100 \mathrm{~kg}$ K), B (200 kg N: $150 \mathrm{~kg}$ P: $100 \mathrm{~kg} \mathrm{~K}: 5.000 \mathrm{~kg}$ pupuk kandang), C (50 kg N: $37.5 \mathrm{~kg}$ P: $25 \mathrm{~kg} \mathrm{~K}$ : $5.000 \mathrm{~kg}$ pupuk kandang: $180 \mathrm{~kg}$ MVA), D (50 kg N: $37.5 \mathrm{~kg}$ P: $25 \mathrm{~kg} \mathrm{~K}: 180 \mathrm{~kg}$ MVA), E (5.000 kg pupuk kandang: $180 \mathrm{~kg}$ MVA). Hasilnya, perlakuan tidak berpengaruh signifikan $(\mathrm{P}>0,05)$ pada produktivitas Rumput Raja. Rata-rata tinggi tanaman adalah: 3,35-3,43 m dan anakan: 7,08-08,20 batang. Kandungan nutrisinya (13,21-13,70\% protein kasar, NDF: 61,98- 62,94\%, ADF: 40,0144,27\%, selulosa: 29,68-33,03\%, hemiselulosa: 17,93-21,96\%, lignin: 08,16 sampai 11,36\%). Produksi adalah (produksi segar 83,95-96,48 ton/ha dan 13,79-19,84 ton bahan kering/ha). Kemudian Benefit Cost Ratio (BCR) adalah 05,31-6,54. Jadi menggunakan sistem LEISA dan pertanian organik, produktivitas Rumput Raja sama dengan dosis $100 \%$ pupuk N, P, dan K $(200 \mathrm{~kg}$ urea/ha, SP-36 $150 \mathrm{~kg} / \mathrm{ha}, \mathrm{KCl} 100 \mathrm{~kg} / \mathrm{ha}$ ).
\end{abstract}

Kata Kunci: Rumput Raja, sistem LEISA, VAM, pupuk NPK, pupuk kandang

\section{ABSTRACT}

The research was aimed at finding out the effect of three farming systems (anorganic farming, LEISA and organic farming) on the productivity of the King Grass at the first harvest. This study used fertilizer $N, P, K$, manure, and vesicular arbuscular mycorrhizae (VAM). An experimental design and analysis of variance with randomized block design (RBD) were the research methods, with 5 kinds of treatment and 4 replicates (groups). It consisted of; A (200 kg N: $150 \mathrm{~kg} \mathrm{P:} 100 \mathrm{~kg} \mathrm{~K}), B(200 \mathrm{~kg} \mathrm{~N}: 150 \mathrm{~kg} \mathrm{P:} 100 \mathrm{~kg} \mathrm{~K}: 5,000 \mathrm{~kg}$ of manure), C (50 kg N: $37.5 \mathrm{~kg}$ $P: 25 \mathrm{~kg} \mathrm{~K}: 5,000 \mathrm{~kg}$ of manure: $180 \mathrm{~kg} \mathrm{MVA),D} \mathrm{(50} \mathrm{kg} \mathrm{N:} 37.5 \mathrm{~kg} \mathrm{P:} 25 \mathrm{~kg} \mathrm{~K}: 180 \mathrm{~kg} \mathrm{MVA}), E$ (5,000 $\mathrm{kg}$ of manure: $180 \mathrm{~kg} \mathrm{MVA).} \mathrm{The} \mathrm{results} \mathrm{showed} \mathrm{that} \mathrm{the} \mathrm{treatment} \mathrm{was} \mathrm{not} \mathrm{significantly}$ affect $(P>0.05)$ the productivity of King Grass. The average grass growth indicators showed (plant height: 3.35-3.43 m, tiller: 7.08-8.20 number rods), nutrient content (crude protein 13.21-13.70\%, NDF: 61.98- 62.94\%, ADF: 40.01-44.27\%, cellulose: 29.68-33.03\%, hemicelluloses: 17.9321.96\%, lignin: 8.16-11.36\%), production (fresh production 83.95-96.48 tons/ha and 13.79-19.84 tons dry matter/ha). Benefit Cost Ratio (BCR) was: 5.31-6.54. The study concluded that by using the LEISA and organic farming systems, King Grass productivity equate to $100 \%$ dosage recommendation of $\mathrm{N}, \mathrm{P}$, and $\mathrm{K}(200 \mathrm{~kg} \mathrm{urea} / \mathrm{ha}, S P-36150 \mathrm{~kg} / \mathrm{ha}, \mathrm{KCl} 100 \mathrm{~kg} / \mathrm{ha})$.

Keywords: King Grass, LEISA systems, VAM, NPK fertilizer, manure 


\section{PENDAHULUAN}

Hijauan sebagai bahan pakan ternak ruminansia di Indonesia memegang peranan penting karena hijauan mengandung hampir semua zat yang diperlukan. Upaya untuk meningkatkan produksi peternakan secara cepat hanya dapat dicapai apabila ditunjang dengan penyediaan pakan yang berkualitas. Bahan pakan hijauan memegang peranan istimewa karena merupakan sumber makanan utama bagi ternak ruminansia untuk dapat bertahan hidup dan berproduksi. Produksi ternak yang tinggi perlu didukung oleh ketersediaan pakan hijauan yang cukup dan kontinu (Suryana, 2009).

Pada saat ini untuk menanggulangi masalah kekurangan pakan hijauan telah diperkenalkan dan dikembangkan bermacammacam jenis hijauan, salah satu sumber utama pakan hijauan adalah berasal dari rumput. Rumput yang sangat potensial dan sering diberikan pada ternak ruminansia adalah rumput raja (Pennisetum purpupoides). Rumput ini merupakan hasil persilangan antara rumput gajah (Pennisetum purpureum) dengan rumput barja (Pennisetum thypoides). Rumput raja adalah tanaman tahunan (perennial), tumbuh tegak membentuk rumpun. Perakarannya dalam, bentuknya mirip dengan tanaman tebu, tingginya 2-4 $\mathrm{m}$ dan apabila dibiarkan tumbuh tegak dapat mencapai $7 \mathrm{~m}$, berbatang tebal dan keras. Rumput raja memiliki pertumbuhan yang sangat cepat mengalahkan. rumput gajah. Produksi rumput raja sangat tinggi dapat mencapai 1.076 ton rumput segar/ha/tahun (Suyitman et al., 2003).

Pada umumnya pakan hijauan ditanam pada lahan marginal yang mempunyai tingkat kesuburan rendah yang dicirikan dengan sifat kimia, fisika, dan biologi yang kurang bagus, sehingga produktivitas tanaman yang ditanam pada lahan ini agak rendah (Artise, 2011). Salah satu upaya untuk mengatasi kekurangan tersebut diantaranya dengan menerapkan metode pertanian berkelanjutan yaitu sistem LEISA. Sistem LEISA (Low External Input and Sustainable Agriculture) merupakan pertanian berkelanjutan dengan input luar rendah yang mengoptimalkan pemanfaatan sumber daya alam (tanah, air, tumbuhan, tanaman, dan hewan) dan manusia (tenaga, pengetahuan, dan keterampilan) yang tersedia di tempat dan layak secara ekonomis, mantap secara ekologis, adil secara sosial dan sesuai dengan budaya (Reijntjes et al., 1999).

Pelaksanaan metode pertanian berkelanjutan ini menggunakan beberapa jenis pupuk kimia, pupuk organik dan cendawan mikoriza arbuskula (CMA) dalam jumlah sedikit. Husin (2002) menyatakan CMA adalah hubungan simbiotik mutualisme antara cendawan (myko) dan akar tanaman (rhiza). CMA memberikan manfaat pada tanaman, antara lain: meningkatkan kapasitas penyerapan unsur hara, meningkatkan ketahanan terhadap kekeringan dan ketahanan terhadap patogen akar. Jamur mikoriza memperoleh energi untuk partumbuhan dan perkembangan atau untuk kelangsungan hidupnya dari kelebihan fotosintat yang ditransfer ke daerah perakaran (Fakuara dan Setiadi, 1990).

Peto (2006) menyatakan bahwa pemberian dosis $100 \%$ pupuk $\mathrm{N}$, $\mathrm{P}$, dan $\mathrm{K}$ yang terdiri atas: pupuk $\mathrm{N}$ (urea) $200 \mathrm{~kg} / \mathrm{ha}, \mathrm{P}$ (SP36) $150 \mathrm{~kg} / \mathrm{ha}$, dan $\mathrm{K}(\mathrm{KCl}) 100 \mathrm{~kg} / \mathrm{ha}$ dapat meningkatkan produksi dan kandungan gizi dari Rumput Raja. Hasil penelitian Noviarman (2006) menyimpulkan bahwa pemberian dosis $25 \%$ rekomendasi pupuk N, P, dan $\mathrm{K}$ dengan inokulasi CMA menghasilkan pertumbuhan dan produksi yang relatif sama dibanding dengan dosis $100 \% \mathrm{~N}$, P, dan K tanpa CMA.

Tujuan penelitian ini untuk mengetahui pengaruh penerapan beberapa sistem pertanian (sistem pertanian anorganik, dan sistem pertanian LEISA) terhadap pertumbuhan, kandungan gizi, dan produksi Rumput Raja. Kegunaan penelitian ini antara lain: untuk memberikan informasi tentang sistem pertanian berkelanjutan, serta mengetahui pengaruh pemberian beberapa jenis pupuk terhadap pertumbuhan Rumput Raja. Hipotesis penelitian ini adalah penerapan sistem LEISA menghasilkan produktivitas Rumput Raja yang sama dengan pemberian dosis $100 \%$ rekomendasi pupuk N, P, dan K $(200 \mathrm{~kg} / \mathrm{ha}$ urea, $150 \mathrm{~kg} / \mathrm{ha} \mathrm{SP}-36,100 \mathrm{~kg} / \mathrm{ha}$ $\mathrm{KCl})$. 


\section{METODE}

Lokasi yang digunakan untuk penanamam hijauan makanan ternak yaitu terletak di Jorong Koto Hilalang 2, Nagari Sungai Langkok, Kecamatan Tiumang, Kabupaten Dharmasraya, Propinsi Sumatera Barat. Luas lahan yang digunakan $298,2 \mathrm{~m}^{2}$ (21,0 $\mathrm{m}$ x 14,2 $\mathrm{m})$. Bibit Rumput Raja dalam bentuk stek, pupuk N (urea), P (SP-36), K (KCl), pupuk kandang (feses sapi), CMA, meteran, timbangan, kantong plastik, alat-alat pertanian dan tulis.

Metode yang dipakai dalam penelitian ini adalah metode eksperimen dengan menggunakan Rancangan Acak Kelompok (RAK) dengan 5 macam perlakuan dan 4 ulangan (kelompok) yang menjadi kelompok adalah kemiringan lahan. CMA yang diinokulasikan sebanyak 10 gram/rumpun (Noviarman, 2006), sedangkan pupuk N, P, K yang diberikan, yaitu dosis $100 \%$, dan $25 \%$ dari yang direkomendasikan. Rekomendasi dosis pupuk $100 \% \mathrm{~N}$, P, dan $\mathrm{K}$ berdasarkan hasil penelitian Peto (2006) yaitu: $200 \mathrm{~kg}$ urea, 150 $\mathrm{kg}$ SP-36 dan $100 \mathrm{~kg} \mathrm{KCl} \mathrm{ha/panen} \mathrm{serta}$ CMA yang diinokulasikan adalah 10 gram/ rumpun selama tanaman hidup. Perlakuan yang diberikan adalah sebagai berikut: Perlakuan A $=100 \%$ N, P, K (200 kg/ha urea $+150 \mathrm{~kg} / \mathrm{ha} \mathrm{SP}-36$ + $100 \mathrm{~kg} / \mathrm{ha} \mathrm{KCl}) ; \mathrm{B}=\mathrm{A}+$ 5 ton pupuk kandang; $\mathrm{C}=25 \% \mathrm{~A}+5$ ton pupuk kandang + CMA; D = 25\% A + CMA; dan perlakuan $\mathrm{E}=5$ ton pupuk kandang + CMA.

Parameter yang diamati adalah: tinggi tanaman, jumlah anakan, produksi segar, produksi bahan kering, kandungan gizi, dan Benefit Cost Ratio (BCR). Rancangan penelitian menggunakan rancangan acak kelompok (RAK). Perbedaan antar perlakuan diuji dengan Duncan's Multiple Range Test (Steel and Torrie, 1991).

\section{HASIL DAN PEMBAHASAN}

Hasil penelitian penerapan beberapa sistem pertanian (system pertanian anorganik, system pertanian LEISA, dan sistem pertanian organik) terhadap produktivitas (pertumbuhan tanaman, kandungan gizi, produksi, dan BCR Rumput Raja (Pennisetum purpupoides) pada pemotongan pertama dapat dilihat pada Tabel 1.

Hasil analisis keragaman menunjukkan bahwa pengaruh pemberian dosis pemupukan $\mathrm{N}$, P, dan K, pupuk kandang serta CMA memberikan pengaruh yang berbeda tidak nyata $(\mathrm{P}>0,05)$ terhadap produktivitas tanaman, yaitu : pertumbuhan vegetatif tanaman (tinggi tanaman dan jumlah anakan), kandungan gizi, produksi (produksi segar dan produksi bahan kering), serta BCR rumput raja pada pemotongan pertama. Kondisi ini mengakibatkan produktivitas Rumput Raja relatif sama pada setiap perlakuan. Hasil penelitian ini juga menunjukkan bahwa dengan menggunakan sistem LEISA (perlakuan C dan D) menghasilkan pertumbuhan vegetatif, kandungan gizi, dan produksi tanaman serta BCR rumput raja pada pemotongan pertama relatif sama dengan sistem pertanian anorganik (perlakuan A dan B). Hal ini disebabkan adanya fungsi CMA yang dapat membantu penyerapan unsur-unsur hara dalam tanah yang diperlukan tanaman untuk pertumbuhan optimal. Pemakaian CMA ternyata dalam penelitian ini bisa menghemat dosis pupuk N, P, K, sebanyak $75 \%$. Sesuai pernyataan Anas dan Santoso (1992) serta Abdullah et al. (2005) bahwa tanaman yang terinfeksi CMA dapat lebih mudah menyerap unsur hara dan air yang tersedia dalam tanah, sehingga dengan pengurangan jumlah pupuk $\mathrm{N}, \mathrm{P}$ dan $\mathrm{K}$ pada tanah, tanaman tidak kekurangan makanan dan mampu meningkatkan pertumbuhan daun.

Peto (2006) menyatakan bahwa rumput raja, gajah dan benggala yang diinokulasi dengan CMA dapat meningkatkan serapan P, pertumbuhan, dan produksi tanpa menurunkan kandungan gizi. CMA juga mampu meningkatkan pertumbuhan tanaman karena status nutrisi tanaman tersebut dapat ditingkatkan dan diperbaiki, terutama untuk daerah yang bermasalah, seperti tanah masam. Setiadi (1994) juga membuktikan bahwa CMA mampu mengurangi atau menghemat kira-kira $50 \%$ kebutuhan $\mathrm{P}, 40 \% \mathrm{~N}$, dan $25 \% \mathrm{~K}$, dan meningkatkan efisiensi pemupukkan. Hal ini 
Tabel 1. Rataan produktivitas Rumput Raja pemotongan pertama menggunakan beberapa sistem pertanian

\begin{tabular}{lrrrrrr}
\hline \multicolumn{1}{c}{ Parameter } & \multicolumn{7}{c}{ Perlakuan } \\
\cline { 2 - 7 } & \multicolumn{1}{c}{ A } & \multicolumn{1}{c}{ B } & \multicolumn{1}{c}{ C } & \multicolumn{1}{c}{ D } & \multicolumn{1}{c}{ E } & \multicolumn{1}{c}{ S.E. } \\
\hline Pertumbuhan tanaman: & & & & & & \\
Tinggi tanaman (cm) & 3,38 & 3,36 & 3,43 & 3,35 & 3,40 & 0,04 \\
Jumlah anakan (batang) & 7,17 & 8,09 & 7,77 & 7,08 & 8,20 & 0,80 \\
Kandungan gizi: & & & & & & \\
Protein kasar (\% BK) & 13,37 & 13,51 & 13.35 & 13,21 & 13,70 & 0,19 \\
N D F (\% BK) & 62,67 & 62,37 & 62,94 & 61,98 & 62,21 & 2,57 \\
A D F (\% BK) & 42,34 & 41,72 & 43,23 & 40,01 & 44,27 & 3,57 \\
Selulosa (\% BK) & 33,03 & 32,31 & 29,89 & 29,68 & 30,87 & 2,85 \\
Hemiselulosa (\% BK) & 20,33 & 20,65 & 18,71 & 21,96 & 17,93 & 3,10 \\
Lignin (\% BK) & 8,16 & 9,66 & 10,78 & 8,46 & 11,36 & 2,09 \\
Produksi: & & & & & & \\
Produksi segar (ton/ha/panen) & 87,46 & 94,52 & 84,09 & 83,95 & 96,48 & 12,13 \\
Produksi B.K. (ton/ha/panen) & 15,41 & 16,90 & 14,57 & 13,79 & 19,84 & 2,36 \\
Benefit Cost Ratio (BCR) & 5,31 & 5,32 & 5,41 & 5,87 & 6,54 & 0,77 \\
\hline
\end{tabular}

disebabkan CMA dapat memperpanjang dan memperluas jangkauan akar terhadap penyerapan unsur hara di dalam tanah, terutama unsur fosfor. CMA juga berperan penting dalam mengefektifkan daur ulang unsur hara sehingga dianggap sebagai alat biologis yang paling efektif untuk mempertahankan stabilitas dan kelestarian ekosistem (Husin, 2002).

Pada Tabel 1 terlihat bahwa penerapan sistem pertanian organik (perlakuan $\mathrm{E}=$ pupuk kandang + CMA) mampu menghasilkan pertumbuhan vegetatif tanaman, kandungan gizi, produksi, dan BCR rumput raja yang sama dengan sistem pertanian anorganik (perlakuan $\mathrm{A}=100 \% \mathrm{~N}, \mathrm{P}$, dan $\mathrm{K}$ ). Hal ini disebabkan fungsi CMA dan pupuk kandang yang mengandung unsur hara yang lengkap yang dibutuhkan oleh aktifitas CMA akan sangat berpengaruh terhadap fisiologis tanaman, sehingga pertumbuhan vegetatif tanaman dapat meningkat. Hal ini didukung oleh pernyataan Husin (2002) dan Chalimah et al. (2007) bahwa penggunaan CMA dapat meningkatkan pertumbuhan dan mendorong pertumbuhan anakan, inokulasi mikoriza juga mampu meningkatkan pertambahan tinggi tanaman serta kandungan hara $\mathrm{N}, \mathrm{P}$, dan $\mathrm{K}$, dan Ca pada daun.

Pemberian pupuk kandang yang mengandung unsur hara makro dan mikro yang lengkap sudah bisa mencukupi kebutuhan pertumbuhan dari rumput raja. Pemberian pupuk kandang menjadikan tanah subur secara fisik, kimia maupun biologis. Secara fisik pupuk kandang membentuk agrerat tanah yang mantap. Keadaan ini besar pengaruhnya terhadap porositas dan aerasi persediaan air dalam tanah, sehingga berpengaruh terhadap perkembangan akar tanaman. Secara kimia, pupuk kandang sebagai bahan organik dapat menyerap bahan yang bersifat racun seperti alumunium $(\mathrm{Al})$, besi $(\mathrm{Fe})$ dan mangan $(\mathrm{Mn})$ serta dapat meningkatkan $\mathrm{pH}$ tanah. Secara biologi, pemberian pupuk kandang ke dalam tanah akan memperkaya jasad renik dalam tanah. Organisme tersebut sangat membantu dalam penguraian bahan organik sehingga tanah lebih cepat matang. Kandungan N, P, K dalam pupuk kandang tidak terlalu tinggi, tetapi jenis pupuk ini dapat memperbaiki permeabilitas tanah, porositas, struktur tanah, daya menahan air, dan kandungan kation rendah (Hardjowigeno, 1995 dan Mayadewi, 
2007). Pupuk kandang sapi termasuk pupuk dingin karena perubahan dari bahan yang terkandung dalam pupuk menjadi tersedia dalam tanah berlangsung secara perlahanlahan (Barus, 2012).

Sutedjo (2010) menyatakan bahwa pemberian pupuk yang mengandung unsur $\mathrm{N}$ akan meningkatkan pertumbuhan vegetatif tanaman, juga dapat mendorong metabolisme unsur-unsur lain seperti $\mathrm{P}$ dan $\mathrm{K}$ dan sebaliknya, dengan demikian pemberian pupuk yang mengandung unsur $\mathrm{N}, \mathrm{P}$ dan $\mathrm{K}$ secara lengkap baik dari pupuk organik maupun pupuk anorganik yang seimbang dapat meningkatkan aktifitas pertumbuhan dan produksi tanaman yang baik. Unsur N, P, dan K sangat berhubungan erat dengan pertumbuhan tanaman, karena $\mathrm{N}$, P dan $\mathrm{K}$ berfungsi untuk merangsang pertumbuhan tanaman secara keseluruhan. Peranan utama nitrogen bagi tanaman ialah untuk merangsang pertumbuhan tanaman secara keseluruhan, khususnya batang, cabang, dan daun. Nitrogen juga berperan penting dalam hal pembentukkan hijauan yang berguna dalam proses fotosintesis, membentuk protein, lemak, dan berbagai persenyawaan organik lainnya. Unsur fosfor bagi tanaman berguna untuk merangsang pertumbuhan akar khususnya akar benih dan tanaman muda. Membantu asimilasi dan pernafasan sekaligus mempercepat pembungaan, pemasakan biji dan buah. Susetyo (1980) menyatakan bahwa unsur fosfor berfungsi memberikan energi dalam proses transpirasi, fotosintesis, pembelahan sel, perkembangan sel (meristem) dan perkembangan akar. Kalium berfungsi dalam pembentukkan protein dan karbohidrat, kalium juga berperan memperkuat tubuh tanaman, agar daun dan buah tidak mudah gugur. Kalium juga sumber kekuatan bagi tanaman menghadapi kekeringan dan penyakit (Rismunandar, 1986). Produksi segar dan produksi bahan kering sejalan dengan partumbuhan vegetatif. Reksohadiprodjo (1985) menyatakan bahwa semakin baik partumbuhan vegetatif suatu tanaman maka produksi (produksi segar dan produksi bahan kering) tanaman tersebut juga akan meningkat.
Hasil analisis keragaman menunjukkan bahwa pemberian beberapa dosis pupuk N, P, dan $\mathrm{K}$, pupuk kandang serta CMA memberikan pengaruh yang berbeda tidak nyata $(\mathrm{P}>0.05)$ terhadap kandungan gizi (kandungan protein kasar dan fraksi serat) rumput raja. Hasil penelitian ini menunjukkan penerapan sistem LEISA (perlakuan C dan D) memberikan hasil yang sama dengan pertanian anorganik (perlakuan A dan B). Hal ini disebabkan fungsi CMA yang membantu meningkatkan penyerapan unsur-unsur hara dalam tanah yang diperlukan tanaman untuk pertumbuhan optimal. Adanya CMA bisa menghemat hingga $75 \%$ dari pupuk $\mathrm{N}, \mathrm{P}$, dan $\mathrm{K}$ bahkan sampai $100 \%$ pada pertanian organik. Hal ini disebabkan CMA merupakan hubungan simbiotik mutualistik antara jamur nonpatogen dengan sel-sel akar tanaman, terutama sel epidermis dan korteks. Jamur memperoleh senyawa organik dari tanaman, sedangkan tanaman memperoleh keuntungan karena penyerapan unsur hara dan air dapat berlangsung lebih baik. Melalui hifa-hifa dari CMA yang berasosiasi dengan akar, tanaman mampu menyerap hara lebih banyak dari dalam tanah, sehingga bisa memperbaiki nutrisi tanaman dan mengurangi pemakaian pupuk. Sesuai dengan pandapat Anas dan Santoso (1992) bahwa simbiosis CMA memberikan keuntungan pada tumbuhan induk semangnya yaitu meningkatkan penyerapan unsur hara, meningkatkan resistensi terhadap logam berat dan patogen tular tanah, bersifat sinergi terhadap mikroba lain, berperan aktif dalam siklus nutrisi, dan meningkatkan stabilitas ekosistem. Didukung oleh pernyataan Husin (2002), bahwa tumbuhan yang bermikoriza dapat menyerap fosfor, nitrogen, dan kalium yang lebih banyak dibandingkan dengan yang tidak bermikoriza pada substrat yang sama.

Selain karena adanya CMA dan pupuk kandang, berbeda tidak nyatanya $(\mathrm{P}>0,05)$ rataan dari masing-masing perlakuan pada penelitian ini juga disebabkan tidak seluruhnya pupuk yang diberikan pada perlakuan A dan B dapat diserap oleh tanaman karena pada tanah ultisol unsur hara banyak hilang melalui 
leaching dan penguapan, sedangkan $\mathrm{P}$ akan diikat oleh $\mathrm{Al}$ dan $\mathrm{Fe}$ membentuk ikatan komplek. Rendahnya unsur hara yang tersedia dan diserap oleh tanaman akan menyebabkan pertumbuhan rumput raja lebih rendah dibandingkan dengan penambahan CMA, begitu juga sebaliknya pertumbuhan yang rendah akan menyebabkan produksi hijauan menjadi lebih rendah. Reksohadiprodjo (1985) menyatakan bahwa produksi segar dan bahan kering serta kandungan gizi erat kaitannya dengan pertumbuhan vegetatif tanaman (tinggi tanaman dan jumlah anakan). Pertumbuhan vegetatif yang sama akan menghasilkan produksi dan kandungan gizi yang sama pula, semakin baik pertumbuhan vegetatif maka akan menghasilkan produksi dan kandungan gizi tanaman yang semakin tinggi.

Pada Tabel 1 menunjukkan bahwa kandungan protein kasar Rumput Raja dengan sistem LEISA (perlakuan C dan D) dan pertanian organik (perlakuan E) menghasilkan kandungan protein kasar tanaman yang relatif sama dibandingkan perlakuan pertanian anorganik (perlakukan A dan B). Hal ini disebabkan adanya fungsi CMA yang dapat membantu penyerapan unsur hara dan menghemat sampai $75 \% \mathrm{~N}, \mathrm{P}$, dan $\mathrm{K}$ serta peran pupuk kandang yang dapat memperbaiki sifat fisik, kimia dan biologi tanah.

Tabel 1 dapat dilihat bahwa rataan NDF berkisar antara 61,98-62,94\%, ADF 41,71$44,27 \%$, selulosa $29,67-33,03 \%$, hemiselulosa 18,51-20,65\%, dan lignin 8,15-11,36\%. Hasil analisis keragaman menunjukan bahwa pemberian takaran dosis $\mathrm{N}, \mathrm{P}$, dan $\mathrm{K}$, pupuk kandang dan CMA yang berbeda dari masingmasing perlakuan memberikan pengaruh yang berbeda tidak nyata $(\mathrm{P}>0,05)$ terhadap fraksi serat rumput raja. Hal ini disebabkan pemberian jenis dan dosis pupuk yang berbeda pada setiap perlakuan tidak mengganggu pertumbuhan sehingga kebutuhan unsur hara telah tercukupi dan memiliki respon yang hampir sama untuk setiap tanaman pada masingmasing perlakuan sehingga tidak mengalami hambatan untuk pembentukan serat kasar pada tanaman itu sendiri.
Namun demikian, jika dilihat dari masing-masing perlakuan, sistem LEISA (perlakuan C dan D) dan organik (perlakuan E) bisa menghasilkan kandungan fraksi serat yang sama dengan pertanian anorganik (perlakuan A dan B). Hal ini disebabkan adanya fungsi CMA yang membantu peyerapan unsur hara yang dibutuhkan oleh tanaman sehinggga tercukupi untuk pertumbuhan optimal, serta pemberian pupuk kandang yang membantu menyediakan kandungan unsur hara mikro dan makro yang lengkap sehingga tanah subur secara fisik, kimia maupun biologis. Adanya fungsi CMA pada sistem LEISA bisa menghemat hingga $75 \%$ pupuk $\mathrm{N}, \mathrm{P}$, dan $\mathrm{K}$, bahkan pada pertanian organik sudah mampu menghemat hingga $100 \%$ pupuk N, P, dan K

Selain itu, adanya hifa-hifa dari CMA yang berasosiasi dengan akar juga dapat menyerap air dari pori-pori tanah. CMA juga berperan aktif dalam siklus nutrisi, sinergi terhadap mikroba lain dan meningkatkan stabilitas ekosistem yang dapat meningkatkan kesuburan tanah sehingga unsur hara yang tersedia meningkat dan mengakibatkan produktivitas (pertumbuhan, produksi, dan kandungan gizi) dari Rumput Raja juga meningkat. Pemberian CMA dan pupuk kandang yang menyediakan unsur $\mathrm{N}, \mathrm{P}$, dan $\mathrm{K}$ yang cukup maka pertumbuhan dan produksi rumput raja menjadi bagus, pertumbuhan dan produksi yang bagus maka kandungan gizi dari rumput raja akan bagus juga. Sesuai pernyataan Husin (2002), bahwa tumbuhan yang bermikoriza dapat menyerap fosfor, nitrogen, dan kalium yang lebih banyak dibandingkan dengan yang tidak bermikoriza pada substrat yang sama. Didukung oleh pernyataan Setiadi (1994), bahwa CMA dapat meningkatkan penyerapan unsur hara dalam tanah. Tanaman bermikoriza umumnya tumbuh lebih baik dari pada tanaman yang tidak bermikoriza karena mikoriza secara aktif meningkatkan penyerapan unsur hara makro dan mikro, selain itu akar yang bermikoriza dapat menyerap unsur hara dalam bentuk terikat dan tidak tersedia untuk tanaman. Anas dan Santoso (1992) menambahkan bahwa simbiosis CMA memberikan keuntungan pada 
tumbuhan induk semangnya yaitu meningkatkan penyerapan unsur hara, meningkatkan resistensi terhadap logam berat dan patogen tular tanah, bersifat sinergi terhadap mikroba lain, berperan aktif dalam siklus nutrisi, dan meningkatkan stabilitas ekosistem.

Pemberian pupuk kandang membantu menyediakan kandungan unsur hara mikro dan unsur hara makro yang lengkap sehingga tanah subur secara fisik, kimia maupun biologis. Secara fisik pupuk kandang membuat tanah menjadi gembur sehingga aerasi dalam tanah menjadi lancar. Secara kimia, pupuk kandang membantu menyediakan unsur N, P, dan $\mathrm{K}$ untuk tanaman dan dapat menyerap bahan yang bersifat racun. Secara biologis, pupuk kandang dapat menambah jasad renik dalam tanah yang membantu dalam penguraian bahan organik sehingga tanah menjadi subur. Sesuai pendapat Hardjowigeno (1995) dan Tola et al. (2007) bahwa pupuk kandang mempunyai pengaruh yang positif terhadap sifat fisik dan kimiawi tanah, mendorong perkembangan jasad renik, dengan kata lain pupuk kandang mempunyai kemampuan mengubah berbagai faktor dalam tanah, sehingga menjadi faktor-faktor yang menjamin kesuburan tanah. Selanjutnya dinyatakan bahwa pupuk kandang tidak hanya membantu pertumbuhan, tetapi juga dapat memperbaiki struktur tanah, membantu penyerapan hara, dan mempertahankan suhu tanah. Pertumbuhan vegetatif yang sama akan menghasilkan kandungan isi sel yang sama. Isi sel terdiri atas zat-zat yang mudah dicerna seperti protein kasar, karbohidrat, lemak kasar dan mineral. Kandungan isi sel yang sama, maka kandungan dari dinding selnya juga akan sama. Dinding sel tersusun atas dua jenis serat yaitu yang tidak larut dalam detergent netral atau sering disebut NDF (selulosa, hemiselulosa, lignin, dan silika) dan yang tidak larut dalam detergent asam yakni ADF (selulosa, lignin, dan silika). Fungsi dinding sel adalah untuk melindungi sel tumbuhan, mempekuat tubuh tanaman, dan menjaga tanaman agar tidak mudah rusak oleh ancaman fisik, kimia, dan biologis. Daya cerna NDF lebih tinggi dibanding daya cerna ADF dalam rumen, karena NDF memiliki fraksi yang mudah larut dalam rumen (Reksohadiprodjo, 1985).

Pada Tabel 1 dapat dilihat bahwa hasil rataan BCR Rumput Raja berkisar antara 5.316.54. Hasil analisis keragaman menunjukkan bahwa antar perlakuan memberikan pengaruh yang berbeda tidak nyata $(\mathrm{P}>0,05)$ terhadap BCR rumput raja. Namun demikian jika dilihat pada hasil penelitian ternyata pada perlakuan D (sistem LEISA) dan E (pertanian organik) lebih menguntungkan dari segi biaya dibandingkan perlakuan lainnya. Hal ini artinya sesuai dengan prinsip ekonomi yaitu pengeluaran biaya yang sedikit dan mendapatkan penghasilan sebesar-besarnya, sehingga BCR pada perlakuan $\mathrm{D}$ dan $\mathrm{E}$ diperoleh yang paling tinggi, yaitu 5,87-6,54, jika disbandingkan dengan perlakuan A $(100 \% \mathrm{~N}, \mathrm{P}, \mathrm{K})$ atau sistem pertanian anorganik. Nilai $\mathrm{BCR}<1$ maka bisa disimpulkan produksi mengalami kerugian, jika BCR $>1$ maka bisa dikatakan produksi mengalami keuntungan dan apabila $\mathrm{BCR}=1$ maka bisa ditetapkan produksi tidak mengalami keuntungan dan juga tidak mengalami kerugian (Hartowo, 1992).

\section{KESIMPULAN}

Berdasarkan hasil penelitian ini dapat disimpulkan bahwa : penerapan sistem LEISA (Low Exsternal Input and Sustainable Agriculture) dan sistem pertanian organik menghasilkan pertumbuhan, kandungan gizi, produksi, dan BCR Rumput Raja yang sama pada pemotongan pertama dengan pemberian dosis $100 \%$ rekomendasi pupuk $\mathrm{N}, \mathrm{P}$, dan K (200 $\mathrm{kg} / \mathrm{ha}$ urea, $150 \mathrm{~kg} / \mathrm{ha} \mathrm{SP}-36,100 \mathrm{~kg} / \mathrm{ha} \mathrm{KCl}$ ). Namun demikian perlakuan yang paling menguntungkan adalah pada perlakuan sistem pertanian LEISA dan sistem pertanian organik.

\section{UCAPAN TERIMAKASIH}

Ucapan terimakasih disampaikan kepada Direktorat Penelitian dan Pengabdian Kepada Masyarakat, Direktorat Jenderal Pendidikan Tinggi, Kementerian Pendidikan dan Kebudayaan, melalui DIPA Universitas Andalas yang telah membiayai penelitian ini melalui skim 
Penelitian Unggulan Strategis Nasional (PUSNAS) sesuai dengan Surat Perjanjian Pelaksanaan Penugasan Penelitian Nomor: 02/UN.16/PL-USN/2014, tanggal 07 Mei 2014.

\section{DAFTAR PUSTAKA}

Abdullah, S., Y. Musa, dan Feranita. 2005. Perbanyakan cendawan mikoriza arbuskula pada berbagai varietas jagung (Zea mays L.) dan pemanfaatannya pada dua varitas tebu (Saccharum officinarum L.). Jurnal Sains dan Teknologi 5:12-20.

Anas, 1. dan D. A. Santoso. 1992. Mikoriza vesikular asbuskular. Bioteknologi pertanian 2. Pusat Antar Universitas Pangan dan Gizi-Instustut Pertanian Bogor, Bogor. Hal: 285-327.

Artise, H.S.S. 2011. Pengembangan ternak sapi lokal berwawasan lingkungan di Sulawesi Utara. Prosid. Seminar Nas. Penelit. dan PKM Sains, Teknologi, dan Kesehatan 2 (1): 545 - 552.

Barus, Y. 2012. Pengaruh aplikasi pupuk kandang dan sistim tanam terhadap hasil varietas unggul padi gogo pada lahan kering masam di Lampung. Jurnal Lahan Suboptimal 1 (1): 102 - 106.

Chalimah, S., Muhadiono, L. Aznam, S. Harran, dan N. Toruan. 2007. Perbanyakan Gigaspora sp. dan Aclauspora sp. dengan kultur pot di rumah kaca. Biodiversitas 7: 12 - 19.

Fakuara, M. Y dan Y. Setiadi. 1990. Aplikasi mikoriza dalam pembangunan industry dalam E. B. Hariyanto. Prosiding Seminar Bioteknologi Hutan. FHUT UGM, Yogyakarta.

Hardjowigeno, S. 1995. Ilmu Tanah. PT. Mediyatama Sarana Perkasa. Jakarta.

Hartowo, S. 1992. Pengantar Ilmu Ekonomi. Cetakan ke-3. Penerbit Universitas Terbuka, Jakarta.

Husin, E. F. 2002. Respon berbagai tanaman terhadap pupuk hayati cendawan mikoriza arbuskula. Pusat Studi dan Pengembangan Agen Hayati (PUSPAHATI). Universitas Andalas, Padang.

Mayadewi, N.N.A. 2007. Pengaruh jenis pupuk kandang dan jarak tanam terhadap pertumbuhan gulma dan hasil jagung manis. Agritrop. 26 (4): $153-$ 159.

Noviarman, R. 2006. Pengaruh dosis pupuk N, $\mathrm{P}$ dan $\mathrm{K}$ pada tanah ultisol yang diinokulasi dengan CMA (Glomus fasciculatum) terhadap produksi, kandungan gizi, dan cost benefit ratio rumput raja (Pennisetum purpupoides) pemotongan pertama. Skripsi, Fakultas Peternakan. Universitas Andalas, Padang.

Peto $_{2}$ M. 2006. Pengaruh dosis pupuk N, P, K terhadap produksi kumulatif dan kandungan gizi rumput raja (Pennisetum purpupoides) pada tanah ultisol yang diinokulasi dengan cendawan mikoriza arbuskula Glomus Manihottis. Penelitian dan Pengembangan Peternakan (KRPP) UPT PeternakanUnand dan Laboratorium Hijauan Pakan Ternak Faterna Unand Pascasarjana Universitas Andalas, Padang.

Reijntjes, C. B. Haverkort, dan A. Watersbayer. 1999. Pertanian Masa Depan: Penghantar untuk Pertanian Berkelanjutan dengan Input Luar Rendah (Terjemah). Kanisius: Yogyakarta.

Reksohadiprodjo, S. 1985. Produksi Tanaman Hijauan Makanan Ternak Tropik. Cetakan I. Penerbit Fakultas Ekonomi Universitas Gadjah Mada, Yogyakarta.

Rismunandar. 1986. Mendayagunakan Tanaman Rumput. Sinar Baru, Bandung.

Salikin, A. Karwan. 2003. Sistem Pertanian Berkelanjutan. Kanisius, Yogyakarta.

Setiadi, Y. 1994. Mengenal mikoriza vecikularis arbuskula sebagai pupuk biologis untuk mereklamasi lahan kritis. 
Pusat Antar Universitas Bioteknologi Institut Pertanian Bogor, Bogor.

Steel, R.G.D. dan J.H. Torrie. 1991. Prinsip dan Prosedur Statistika Suatu Pendekatan Biometri. Edisi Ke-2, Cet2. Alih Bahasa: B. Sumantri. PT. Gramedia Pustaka Utama, Jakarta.

Suryana. 2009. Pengembangan usaha ternak sapi potong berorientasi agribisnis dengan pola kemitraan. Balai Pengkajian Teknologi Pertanian Kalsel. Jurnal Litbang Pertanian 28 (1): 29 - 36.

Susetyo, S. 1980. Padang pengembalaan. Departemen Ilmu Makanan Ternak. IPB, Bogor.
Sutedjo, M. M. 2010. Pupuk dan Cara Pemupukan. Rineka Cipta, Jakarta.

Suyitman, S. Jalaludin, Abudinar, N. Muis, Ifradi, N. Jamaran, M. Peto, dan Tanamasni. 2003. Agrostologi. Fakultas Peternakan Universitas Andalas, Padang.

Tola, F. Hamzah, Dahlan, dan Kharuddin. 2007. Pengaruh penggunaan dosis pupuk bokashi kotoran sapi terhadap pertumbuhan dan produksi tanaman jagung. Jurnal Agrisistem 3 (1): $1-8$. 